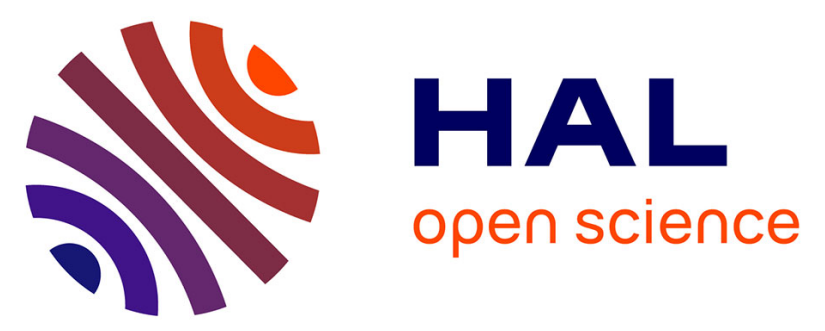

\title{
Composition, antibacterial and antioxidant activities of Pimpinella saxifraga essential oil and application to cheese preservation as coating additive
}

Ghada Ksouda, Sabrine Sellimi, Franck Merlier, Aude Falcimaigne-Cordin, Brigitte Thomasset, Moncef Nasri, Mohamed Hajji

\section{To cite this version:}

Ghada Ksouda, Sabrine Sellimi, Franck Merlier, Aude Falcimaigne-Cordin, Brigitte Thomasset, et al.. Composition, antibacterial and antioxidant activities of Pimpinella saxifraga essential oil and application to cheese preservation as coating additive. Food Chemistry, 2019, 288, pp.47-56. 10.1016/j.foodchem.2019.02.103 . hal-02058774

\section{HAL Id: hal-02058774 \\ https://hal.utc.fr/hal-02058774}

Submitted on 8 Mar 2019

HAL is a multi-disciplinary open access archive for the deposit and dissemination of scientific research documents, whether they are published or not. The documents may come from teaching and research institutions in France or abroad, or from public or private research centers.
L'archive ouverte pluridisciplinaire HAL, est destinée au dépôt et à la diffusion de documents scientifiques de niveau recherche, publiés ou non, émanant des établissements d'enseignement et de recherche français ou étrangers, des laboratoires publics ou privés. 


\section{Accepted Manuscript}

Composition, antibacterial and antioxidant activities of Pimpinella saxifraga essential oil and application to cheese preservation as coating additive

Ghada Ksouda, Sabrine Sellimi, Franck Merlier, Aude Falcimaigne-cordin, Brigitte Thomasset, Moncef Nasri, Mohamed Hajji

PII: S0308-8146(19)30435-2

DOI: https://doi.org/10.1016/j.foodchem.2019.02.103

Reference: FOCH 24415

To appear in:

Food Chemistry

Received Date:

10 September 2018

Revised Date:

21 February 2019

Accepted Date:

22 February 2019

Please cite this article as: Ksouda, G., Sellimi, S., Merlier, F., Falcimaigne-cordin, A., Thomasset, B., Nasri, M., Hajji, M., Composition, antibacterial and antioxidant activities of Pimpinella saxifraga essential oil and application to cheese preservation as coating additive, Food Chemistry (2019), doi: https://doi.org/10.1016/j.foodchem. 2019.02.103

This is a PDF file of an unedited manuscript that has been accepted for publication. As a service to our customers we are providing this early version of the manuscript. The manuscript will undergo copyediting, typesetting, and review of the resulting proof before it is published in its final form. Please note that during the production process errors may be discovered which could affect the content, and all legal disclaimers that apply to the journal pertain. 
Composition, antibacterial and antioxidant activities of Pimpinella saxifraga essential oil and application to cheese preservation as coating additive

Ghada KSOUDA ${ }^{1, a,{ }^{*}, \text { Sabrine SELLIMI }}{ }^{1, \mathrm{a}}$, Franck MERLIER ${ }^{2}$, Aude FALCIMAIGNE-CORDIN $^{2}$, Brigitte THOMASSET ${ }^{2}$, Moncef NASRI ${ }^{1}$, Mohamed HAJJI $^{1}$.

${ }^{1}$ Laboratory of Enzyme Engineering and Microbiology, National School of Engineering of Sfax (ENIS), University of Sfax, P.O. Box 1173, Sfax 3038, Tunisia

${ }^{2}$ Sorbonne Universités, Université de Technologie de Compiègne, UMR -CNRS 7025, Génie Enzymatique et Cellulaire (GEC), CS 60319, 60203 Compiegne Cedex, France

\footnotetext{
${ }^{a}$ The authors Ksouda, G. and Sellimi, S. contributed equally to this work

* Corresponding author

E-mail address: ghadaksouda@ hotmail.fr (G. KSOUDA)
} 


\section{Abstract}

The effect of Pimpinella saxifraga essential oil (PSEO) addition (1-3\%) in sodium alginate coating on the bacterial and oxidative stability of cheese was studied during refrigerated storage. The GC-HRMS analysis of PSEO showed that anethole, pseudoisoeugenol and $p$-anisaldehyde were the main components. The PSEO exhibited strong in vitro DPPH radical scavenging activity $\left(\mathrm{IC}_{50}=6.81 \mu \mathrm{g} / \mathrm{mL}\right), \beta$-carotene bleaching inhibition $\left(\mathrm{IC}_{50}=206 \mu \mathrm{g} / \mathrm{mL}\right)$, ferric reducing power $\left(\mathrm{EC}_{50}=35.20 \mu \mathrm{g} / \mathrm{mL}\right)$, total antioxidant activity $(213.96 \pm 11.12 \mu \mathrm{mol} / \mathrm{mL} \alpha$-tocopherol equivalent $)$ and notable DNA protection potential. Additionally, PSEO displayed potent antibacterial activity against 3 Gram-positive and 3 Gram-negative bacteria (MICs $=0.78-3.12 \mathrm{mg} / \mathrm{mL}$ ). The acute toxicity of PSEO was determined using mice model $\left(\mathrm{LD}_{50}=976.2 \mathrm{mg} / \mathrm{kg}\right)$. The enrichment of sodium alginate coating with PSEO, particularly at 3\%, improved cheese preservation by reducing the weight loss, preserving the $\mathrm{pH}$ and color and enhancing oxidative and bacterial stability without unpleased flavor for consumers.

Keywords: Pimpinella saxifraga essential oil, chemical composition, anethole, antibacterial and antioxidant activities, acute toxicity, coating, bacterial and oxidative stability, sensory analysis 


\section{Introduction}

Essential oils are natural mixtures of volatile and versatile compounds characterized by a strong odor. They are secondary metabolites synthesized by plants to protect them against viruses, microorganisms and insects. They can be produced by all the organs of aromatic plants namely buds, flowers, leaves, stems, seeds, fruits and roots, then stored in secretory epidermal cells, canals, glandular trichomes and cavities (Sangwan, Farooqi, Shabih, \& Sangwan, 2001). Essential oils were basically used in folk medicine as analgesic, antispasmodic, anti-rheumatic and anti-epileptic (Adorjan \& Buchbauer, 2010). Nowadays, there is a growing interest in the use of the essential oils, endowed with biological activities, in pharmaceutical, cosmetic and food fields in order to respond to critical problems such as bacterial resistance and synthetic antioxidants (Burt, 2004). In fact, controlling bacterial infections is becoming an important issue as a result of the developed resistance of bacteria against a large spectrum of commercial antibiotics (Fair \& Tor, 2014). Another matter of concern is the use of synthetic antioxidants which has been suspected to have harmful effects on human health such as toxic and carcinogenic risks (Augustyniak et al., 2010). Thus, the increasing bacterial resistance and the intensive demands for natural antioxidants have motivated the researchers to explore plants as a source of new components with antimicrobial and antioxidant potential such as essential oils.

In plant kingdom, the essential oil is a very complex combination of almost 20 to 60 compounds at considerably different concentrations which influences their biological properties. For example, the Apiaceae family is the focus of many studies due to its large number of aromatic plants producing essential oils with antibacterial and antioxidant activities like caraway, cumin, parsley, anise, dill, fennel and coriander (Khalil, Ashour, Fikry, Singab, \& Salama, 2017). In this case, anethole, a terpenoid widely found in Apiaceae essential oils and usually used as sweet flavoring agent, is known to be highly effective against bacteria and fungi (Marinov \& Valcheva- 
Kuzmanova, 2015). Hence, the analysis of the essential oil composition is primordial to predict its biological effects.

Essential oils are conventionally known as natural safe components with antimicrobial effect but once the required doses are exceeded, they can become toxic and damage the human health (Tisserand \& Young, 2013). Consequently, the study of the acute toxicity of essential oil is crucial to a non-toxic use especially in food industry.

Essential oils are usually lipophilic, volatile and almost insoluble in water. As it is a challenge to incorporate them directly in food, they need to be introduced in a matrix that is compatible with food applications, serving as vector of the bioactive components of essential oils and reducing their possible toxicity (Ju et al., 2018). Sodium alginate, a polysaccharide obtained from seaweeds, is film-forming compound with great mechanical capacities and usually used as potential coating material in foods and drugs (Tavassoli-Kafrani, Shekarchizadeh, \& MasoudpourBehabadi, 2016). In order to improve the shelf life of food, active sodium alginate coatings endowed with antibacterial effect have been developed by the addition of essential oils (TavassoliKafrani et al., 2016).

The plant Pimpinella saxifraga of the Apiaceae family was screened for essential oil extracted from aerial parts and roots (Grys et al., 2009; Masoudi, Rustaiyan, \& Mazloomifar, 2009), while the present work focuses on the essential oil of $P$. saxifraga seeds. Thus, the purposes of the current study are to investigate the chemical composition of $P$. saxifraga essential oil (PSEO) and evaluate its antibacterial and antioxidant activities. The acute toxicity of PSEO is also studied by the assessment of the median lethal dose $\left(\mathrm{LD}_{50}\right)$ on mice model. Furthermore, this work describes the effect of PSEO incorporation in sodium alginate coating on the bacterial and oxidative stability of cheese during refrigerated storage. This study will contribute to the progress of the use of new natural bioactive compounds in food preservation. 


\section{Materials and methods}

\subsection{Essential oil extraction}

The seeds of P. saxifraga were collected from Sidi Bouzid in Tunisia between April and November 2016 and identified in Faculty of Sciences of Sfax (Tunisia). The essential oil was extracted by hydrodistillation of ground seeds $(25 \mathrm{~g})$ for $3 \mathrm{~h}$ in a Clevenger-type apparatus as described by Lo Cantore, Iacobellis, De Marco, Capasso, \& Senatore (2004). This operation was repeated ten times and PSEO fractions were pooled to obtain enough material for experiments. The essential oil was dried using anhydrous sodium sulfate and stored in a dark glass vial at $4{ }^{\circ} \mathrm{C}$ until analysis.

\subsection{GC-HRMS Orbitrap analysis}

The volatile compounds were identified by GC-MS/MS (QExactive ${ }^{\mathrm{TM}}$ GC Orbitrap ${ }^{\mathrm{TM}}$, Thermo-Fisher, Villebon, France), using BP5 MS capillary column (SGE, $30 \mathrm{~m}$ x 0.25 mm, 0.25 $\mu \mathrm{m})$. The carrier gas was helium at a flow rate of $1.2 \mathrm{~mL} / \mathrm{min}$. The oven temperature was initially held at $40{ }^{\circ} \mathrm{C}$ for 2 min after injection, then increased to $350{ }^{\circ} \mathrm{C}$ with a $3{ }^{\circ} \mathrm{C} /$ min heating ramp and kept at $350{ }^{\circ} \mathrm{C}$ for $2 \mathrm{~min}$. The PSEO $(1 \mu \mathrm{L})$ was injected at $250{ }^{\circ} \mathrm{C}$ on mode splitless or with split ratio of $1 / 5$. Mass spectrometer monitoring and spectral processing were released by Xcalibur software (Ver. 4.0.27) and the 2014 NIST database and an internally elaborated HRMS library. Mass spectra of electronic ionization and chemical ionization were recorded. The HRMS system acquired data in the range of $50-550 \mathrm{~m} / \mathrm{z}$ at 60,000 -resolution mode with an energy of $70 \mathrm{eV}$ for electronic ionization. Methane was used at a flow rate of $1.5 \mathrm{~mL} / \mathrm{min}$ in chemical ionization. The spectrometer was calibrated externally. 


\subsection{Antioxidant activity}

\subsubsection{DPPH radical scavenging capacity}

The DPPH (1,1-diphenyl-2-picrylhydrazyl) radical-scavenging ability of PSEO was assessed as described by Bersuder et al. (1998). The DPPH radical scavenging capacity was determined by the following formula:

\section{DPPH radical scavenging activity $(\%)=\left(\mathrm{OD}_{0}-\mathrm{OD}_{1}\right) / \mathrm{OD}_{0} \times 100$}

where $\mathrm{OD}_{0}$ was the absorbance of the control (without the PSEO sample) and $\mathrm{OD}_{1}$ was the absorbance of the test sample (PSEO).

The inhibitory concentration $\left(\mathrm{IC}_{50}\right)$ of PSEO at which DPPH radicals were scavenged by $50 \%$ was assessed by linear regression of the concentration-response curve. The synthetic commercial antioxidant Butylated hydroxyl-anisole (BHA) was used as standard. The test was conducted in triplicate.

\subsection{2. $\beta$-carotene bleaching assay}

The inhibition of $\beta$-carotene bleaching by PSEO was assessed as described by Marco (1968). First, a $\beta$-carotene/linoleic acid emulsion was prepared by dissolving $0.5 \mathrm{mg}$ of $\beta$-carotene, $25 \mu \mathrm{L}$ of linoleic acid and $200 \mu \mathrm{L}$ of Tween 40 in $1 \mathrm{~mL}$ of chloroform. The chloroform was then totally evaporated under vacuum using a rotatory evaporator at $50{ }^{\circ} \mathrm{C}$. A volume of $100 \mathrm{~mL}$ of distilled water was added and the resulting emulsion was vigorously stirred. Thereafter, $2.5 \mathrm{~mL}$ of the $\beta$-carotene/linoleic acid emulsion were mixed with $0.5 \mathrm{~mL}$ of PSEO at different concentrations $(100-700 \mu \mathrm{g} / \mathrm{mL})$. The absorbance was measured at $470 \mathrm{~nm}$ before and after incubation at $50{ }^{\circ} \mathrm{C}$ for $2 \mathrm{~h}$ by UV-Vis spectrophotometry (Agilent, USA). BHA was the positive control. Tests were conducted in duplicate and the $\beta$-carotene bleaching inhibition was calculated using the following formula: 
Inhibition of $\beta$-carotene bleaching $(\%)=\left[1-\left(\left(\mathrm{OD}_{0}-\mathrm{OD}_{\mathrm{t}}\right) /\left(\mathrm{OD}_{0^{-}}^{\prime} \mathrm{OD}_{\mathrm{t}}^{\prime}\right)\right)\right] \times 100$

where $\mathrm{OD}_{0}$ and $\mathrm{OD}_{\mathrm{t}}$ were the absorbances of the test sample (PSEO) measured before and after incubation, respectively; and $\mathrm{OD}_{0}^{\prime}$ and $\mathrm{OD}_{\mathrm{t}}^{\prime}$ were the absorbances of the control measured before and after incubation.

\subsubsection{Reducing power assay}

The capacity of PSEO to reduce iron (III) was evaluated using the approach of Yildirim et al. (2001). The absorbance was recorded at $700 \mathrm{~nm}$. Higher absorbance of test sample indicated higher iron reducing capacity. The commercial antioxidant BHA was used as positive control. The test was conducted in duplicate. The $\mathrm{EC}_{50}$ value, defined as the effective concentration at which the absorbance was 0.5 at $700 \mathrm{~nm}$, was obtained by linear regression analysis.

\subsubsection{Total antioxidant activity}

The total antioxidant capacity was determined on the basis of the reduction of Mo (VI) by PSEO to Mo (V) leading to the formation of a green phosphate-Mo (V) complex in acid solution (Prieto, Pineda, \& Aguilar, 1999). The total antioxidant capacity was considered in terms of $\alpha$-tocopherol equivalents $(\mu \mathrm{mol} / \mathrm{mL})$. The test was done in duplicate.

\subsubsection{DNA nicking assay}

DNA nicking assay was performed using the method of Lee et al. (2002). The PSEO at the concentration of $0.625,1.25$ and $2.5 \mathrm{mg} / \mathrm{mL}$ was mixed with plasmid DNA, respectively. Native plasmid was used as control. Fenton's reagent was added after incubation. The mixture was then incubated for $5 \mathrm{~min}$ at $37{ }^{\circ} \mathrm{C}$. The DNA was analyzed on $0.8 \%(\mathrm{w} / \mathrm{v})$ agarose gel electrophoresis and visualized under ultraviolet light. The intensity of DNA was detected by Bio-Rad's Image Lab software (version 2.0). The retention of supercoiled plasmid DNA strand (\%) was calculated by the following formula: 


$$
\text { Retention }(\%)=\frac{\text { Intensity of supercoiled DNA of sample }}{\text { Intensity of supercoiled DNA of control }} \times 100
$$

\subsection{Antibacterial activity}

\subsubsection{Bacterial strains}

The antibacterial activity was studied against 6 bacterial strains from the American Type Culture Collection: Escherichia coli (ATCC 25922), Pseudomonas aeruginosa (ATCC 27853), Salmonella Typhimurium (ATCC 19430), Listeria monocytogenes (ATCC 19117), Micrococcus luteus (ATCC 4698) and Bacillus cereus (ATCC 11778) which were obtained from the microbial collection of the Centre of Biotechnology of Sfax (Tunisia).

\subsubsection{Agar diffusion method}

The antibacterial activity was assessed as described by Valgas, Souza, Smânia, \& Smânia Jr. (2007). Culture suspensions $(300 \mu \mathrm{L})$ of test microorganisms $\left(10^{6}\right.$ colony forming units $(\mathrm{CFU} / \mathrm{mL})$ estimated by absorbance measurement at $600 \mathrm{~nm}$ ) were spread on Luria-Bertani agar (LB, Thermo-Fisher, Villebon, France). Then, $60 \mu \mathrm{L}$ of PSEO (1\% w/v in dimethyl sulfoxide (DMSO)) were loaded into wells $(6 \mathrm{~mm}$ in diameter) already punched in the agar layer. The Petri dishes were kept at $4{ }^{\circ} \mathrm{C}$ for $1 \mathrm{~h}$ and then incubated for $24 \mathrm{~h}$ at $37^{\circ} \mathrm{C}$. Antimicrobial activity was estimated by measuring the zone of growth inhibition (diameter expressed in millimeters) around the wells. Gentamicin was used as positive standard to determine the sensitivity of bacterial strains and DMSO was used as negative control. The antibacterial activity was performed in triplicate.

\subsubsection{Minimum inhibitory concentration (MIC) and minimum bactericidal concentration $(\mathrm{MBC})$ determination}

The minimum inhibitory concentration (MIC) is defined as the lowest concentration of PSEO which inhibits the visible bacterial growth after overnight incubation (Andrews, 2001). It was determined as reported by Valgas, Souza, Smânia, \& Smânia Jr. (2007) in sterile 96-well 
microplates with a final volume of $200 \mu \mathrm{L}$ per well. Two fold serial dilution of PSEO (dissolved in Tween $80(1 \% \mathrm{v} / \mathrm{v}))$ was performed in LB broth medium. Thereafter, $20 \mu \mathrm{L}$ of each bacterial suspension was inoculated. Each well included $100 \mu \mathrm{L}$ of PSEO diluted in LB broth medium, $80 \mu \mathrm{L}$ of the growth medium (LB) and $20 \mu \mathrm{L}$ of cell suspension $\left(10^{6} \mathrm{CFU} / \mathrm{mL}\right)$. Bacteria only in $\mathrm{LB}$ medium and Tween $80(1 \% \mathrm{v} / \mathrm{v})$ were used as positive and negative controls, respectively. After the incubation of the plates for $24 \mathrm{~h}$ at $37{ }^{\circ} \mathrm{C}, 25 \mu \mathrm{L}$ of 3-(4,5-dimethylthiazol-2-yl)-2,5diphenyltetrazolium bromide (MTT) $(0.5 \mathrm{mg} / \mathrm{mL})$ were added to the wells. The reaction of viable cells with MTT generates violet color. To estimate the MBC, an aliquot of $20 \mu \mathrm{L}$ from each well presented no visible growth were spread on LB dishes. The minimum bactericidal concentration (MBC) was the lowest concentration of antibacterial agent that killed at least $99.9 \%$ of the starting inoculum after $24 \mathrm{~h}$ of incubation at $37^{\circ} \mathrm{C}$ (Andrews, 2001). The determination of MIC and MBC values was assessed in duplicate (expressed in $\mathrm{mg} / \mathrm{mL}$ ).

To determine the MBC, aliquots of $20 \mu \mathrm{L}$ from all dilutions not showing any bacterial growth were spread onto LB agar plates and incubated $\left(37^{\circ} \mathrm{C}, 24 \mathrm{~h}\right)$. The minimum concentration for which there is no visible growth on agar plate was recorded as MBC

\subsection{Acute toxicity}

\subsubsection{Animals}

In this study, a population of Balb/C mice (24-29 g) of female sex was divided into 8 groups of 8 mice each. The mice were fasted for $12 \mathrm{~h}$ before measuring weight and they were used only once in this experiment. Standard pellet diet and water were provided to all groups. The experimental protocol was approved by the Local Animal Care Committee at Sfax University, Tunisia. The manipulation procedure applied in this study was in conformity with the International Guidelines for Animal Care (The European Parliament and the Council of the European union, 2010). 


\subsubsection{Determination of the median lethal dose $\left(\mathrm{LD}_{50}\right)$}

Serial doses of 25, 50, 75, 100, 150 and $350 \mathrm{mg} / \mathrm{mL}$ of PSEO diluted in Tween 80 (1\% v/v), as described by Hilan et al. (2009), were administrated by intraperitoneal injection to 6 groups in a proportion of $0.01 \mathrm{~mL} / \mathrm{g}$ of mice body weight. One group, served as vehicle control, received Tween $80(1 \% \mathrm{v} / \mathrm{v})$ and one untreated group served as normal control. All groups were placed under observation, symptoms of toxicity were noted and the mortality rate was checked for mice during the next 15 days. By the end of this period, dead mice were counted to determine the $\mathrm{LD}_{50}$ by the logarithmic regression analysis of the dose-response curve. The mortality rate is calculated using the following formula:

Number of dead mice in a group

$$
\text { Mortality rate }(\%)=\frac{\text { Total number of mice in a group }(\mathrm{N}=8)}{0100}
$$

\subsection{Cheese coating with alginate containing $P$. saxifraga essential oil}

\subsubsection{Preparation of cheese samples}

Sodium alginate (SA: High molecular weight sodium alginate Protanal ${ }^{\circledR}$ RF6650; FMC, Belgium) coating solutions (2\%, w/v) were prepared by dissolving $2 \mathrm{~g}$ in $100 \mathrm{~mL}$ distilled water with constant stirring at $50{ }^{\circ} \mathrm{C}$ until complete dissolution. Glycerol $(15 \%$, w/w, based on SA content) was then added and the mixture was stirred for $2 \mathrm{~h}$ at room temperature. The PSEO at different proportions $1 \%, 2 \%$ and $3 \%$ (w/w, based on SA content) was then added to each SA coating solution respectively. The mixtures were maintained under continuous stirring (DLS Stirrer, Velp Scientifica Germany, $500 \mathrm{rpm}$ ) to obtain homogeneous solutions. Thereafter, "Béja Sicilian cheese" (fresh cheese) was cut into 24 uniform cubes $\left(80 \mathrm{~g}\right.$ ), sizing $25 \mathrm{~mm}^{3}$, divided in six groups according to the treatment: untreated control samples, samples coated with SA solution only, samples coated with SA solutions containing 1\%, 2\% and 3\% PSEO (w/w, based on SA content) 
and samples coated with SA solution containing $1 \%$ of vitamin $\mathrm{C}$ (w/w, based on SA content) used as standard. Coating was applied by dipping Sicilian cheese cubes into the different SA solutions during two minutes at room temperature. Cheese samples were air-dried and stored at $4{ }^{\circ} \mathrm{C}$ in transparent polypropylene plastic boxes with $95 \%$ relative humidity until analyses.

\subsubsection{Evaluation of weight loss}

The weight loss of the cheese samples on days 4, 7 and 10 days was calculated by the following equation:

$$
\text { Weight loss }(\%)=\left(\mathrm{W}_{0}-\mathrm{W}_{\mathrm{t}}\right) / \mathrm{W}_{0} \times 100
$$

where $\mathrm{W}_{0}$ is the initial weight of sample and $\mathrm{W}_{\mathrm{t}}$ is the weight of the same sample after 4,7 and 10 days of storage at $4{ }^{\circ} \mathrm{C}$.

\subsubsection{Evaluation of water activity, $\mathrm{pH}$ and color}

The $\mathrm{pH}$ and $\mathrm{a}_{\mathrm{w}}$ were measured by a Metrohom $744 \mathrm{pH}$ meter (Metrohm, Switzerland) and a NOVASINA $\mathrm{a}_{\mathrm{w}}$ Sprint TH-500 apparatus (Novasina, Switzerland), respectively. The measurements were performed at $25^{\circ} \mathrm{C}$. CIELAB coordinates ((lightness $\left(\mathrm{L}^{*}\right)$, redness $\left(\mathrm{a}^{*}\right)$ and yellowness $\left(\mathrm{b}^{*}\right)$ ) of the different samples were recorded using a MS/Y-2500 spectrophotometer (Hunterlab, USA).

\subsubsection{Microbiological analysis}

The microbiological analysis was determined according to the approach of Berghe and Vlietinck (2011). Cheese ( $1 \mathrm{~g})$ from the different groups was homogenized with $9 \mathrm{~mL}$ of $1 \% \mathrm{NaCl}$ solution. Ten-fold serial dilutions of these homogenates were performed and used in bacterial enumeration. Total mesophilic bacteria counts were conducted by the pour plate approach using plate count agar (PCA; Sigma-Aldrich, USA) and incubated for $24 \mathrm{~h}$ at $37 \pm 1{ }^{\circ} \mathrm{C}$. Lactic acid bacteria counts were performed by surface seeding method using Man, Rogosa and Sharpe agar plates (MRS; Microxpress, India). After incubation for $24 \mathrm{~h}$ at $37 \pm 1{ }^{\circ} \mathrm{C}$, colonies counts were 
recorded. Bacterial counts were presented as logarithms of colony-forming units per gram of cheese $(\log \mathrm{CFU} / \mathrm{g})$.

\subsubsection{Lipid peroxidation}

Lipid peroxidation of samples throughout the storage period was evaluated according to the method reported by Buege and Aust (1978). The formation of thiobarbituric acid reactive substances (TBARS) such as malondialdehydes (MDA) was estimated on the basis of their reactivity with TBA in an acidic condition to generate pink colored chromosphere. Sicilian cheese sample $(0.5 \mathrm{~g})$ was homogenized with $525 \mu \mathrm{L}$ of TBS $(150 \mathrm{mM} \mathrm{NaCl}$ and $50 \mathrm{mM}$ Tris, $\mathrm{pH} 7.4)$ and $375 \mu \mathrm{L}$ of TCA-BHT (Butylated hydroxytoluene) (TCA 20\%, BHT 1\%) to precipitate proteins, and then centrifuged $\left(1000 \mathrm{~g}, 15 \mathrm{~min}, 4^{\circ} \mathrm{C}\right)$. A volume of $400 \mu \mathrm{L}$ of the supernatant was mixed with 80 $\mu \mathrm{L}$ of $\mathrm{HCl}(0.6 \mathrm{M})$ and $320 \mu \mathrm{L}$ of Tris-TBA (26 mM Tris and $120 \mathrm{mM}$ TBA). The mixture was then incubated for $10 \mathrm{~min}$ at $90{ }^{\circ} \mathrm{C}$. After cooling, the absorbance was recorded on a UV-Vis spectrophotometer (Agilent, USA) at $530 \mathrm{~nm}$. The TBARS values were calculated based on a standard curve of MDA (expressed as $\mu \mathrm{g}$ MDA/100 g cheese).

\subsubsection{Sensory analysis}

The consumer acceptance of coated cheese was conducted by sensory evaluation inspired from Abid, Yaich, Hidouri, Attia, \& Ayadi (2018) works. Cheese samples were served at room temperature $\left(26^{\circ} \mathrm{C}\right)$, within $24 \mathrm{~h}$ after preparation, under normal light conditions in paper plates marked with two-digit randomized codes. Color, flavor, odor, aspect, and texture were evaluated by a panel of 21 untrained random subjects of both genders using the five-point hedonic scale; 1 (Not acceptable), 2 (fair acceptable), 3 (acceptable), 4 (very acceptable), 5 (highly acceptable). Each subject tested approximately the same amount of each cheese sample. 


\subsubsection{Statistical analyses}

Statistical analyses were performed by IBM SPSS ver.22.0. The mean differences between groups were estimated by Duncan test and compared using the one way analysis of variance (ANOVA). Differences were considered significant at $p$-value $<0.05$.

\section{Results and discussion}

\subsection{Chemical composition of Pimpinella saxifraga essential oil}

The extraction yield of the essential oil from $P$. saxifraga ground seeds was $1.12 \%(\mathrm{~g}$ essential oil/100 g dry weight). As observed in Table 1, the analysis of PSEO by GC-HRMS Orbitrap revealed 15 components representing $93.5 \%$ of the total composition. PSEO was mainly composed of anethole (59.47\%) and pseudoisoeugenol (20.15\%) belonging to the phenylpropenoids family (Supplementary Fig. 1). The study of Grys et al. (2009) showed that the essential oil of $P$. saxifraga roots collected from Poland contained limonene, $\alpha$-pinene and $p$-cymen. However, the essential oil extracted from the whole aerial part of $P$. saxifraga in Iran was rich in trans- $\alpha$ bergamotene, $\beta$-bisabolene and $\beta$-sesquiphellandrene (Masoudi et al., 2009). The observed essential oils composition changes could be related to geographical and plant differences. Previous studies have shown that the Pimpinella genus namely $P$. anisum and $P$. anisetum contain high amounts of anethole (80-94\% and 82.8\%, respectively) (Arslan, Gürbüz, Sarihan, Bayrak, \& Gümüşçü, 2004; Tepe et al., 2006). This phenolic derivate was also detected in the essential oils of many species of the Apiaceae family such as Foeniculum vulgare (70.1\%) and Anethum graveolens (11\%) (Gulfraz et al., 2008; Singh, Maurya, Lampasona, \& Catalan, 2005). The second most abundant compound in PSEO was pseudoisoeugenol (20.15\%) which is an isomer of eugenol found in the essential oil of P. anisum fruits and roots (Santos et al., 1998). In fact, it has been proposed that pseudoisoeugenol is synthetized by NIH shift of anethole which involved the migration of a hydrogen atom on an aromatic ring during a hydroxylation reaction (Reichling \& Rainer, 1990). This could explain the 
simultaneous abundance of anethole and pseudoisoeugenol in PSEO. $P$-anisaldehyde and anisketone occurred at different concentrations (7.53 and $1.71 \%$, respectively). These aromatic compounds are mostly present in aniseed essential oil but they could be found in other species especially those of the Apiaceae family like fennel (Arslan et al., 2004; Gulfraz et al., 2008).

\subsection{Evaluation of the antioxidant activity of $P$. saxifraga essential oil}

The antioxidant capacity of PSEO was evaluated using five complementary tests, namely the scavenging ability of the DPPH radicals, the $\beta$-carotene bleaching assay, the iron (III) reducing power ability, the total antioxidant activity and the oxidative damage DNA protective assay. The results are presented in Fig. 1.

\subsubsection{DPPH radical scavenging capacity}

Free radical scavenging is thought to be one of the main mechanisms exhibited by antioxidants to delay oxidative processes. $\mathrm{DPPH}^{\bullet}$ is a stable free radical which accepts an electron or hydrogen radical to become a stable diamagnetic molecule. As shown in Fig. 1A, the DPPH radical scavenging activity increased with PSEO concentration increasing. PSEO exhibited a very strong radical scavenging ability $\left(\mathrm{IC}_{50}=6.81 \mu \mathrm{g} / \mathrm{mL}\right.$ ). This result is similar to the $\mathrm{IC}_{50}$ obtained by Tepe et al. (2006) for the essential oils of P. anisetum $(5.62 \mu \mathrm{g} / \mathrm{mL})$ and P. flabellifolia (8.49 $\mu \mathrm{g} / \mathrm{mL}$ ). It has been proved in a previous study that pure anethole showed a moderate radical scavenging capacity in comparison with BHT (Freire, Morais, Catunda, \& Pinheiro, 2005). Consequently, anethole presenting $59.47 \%$ of the PSEO, could not be only responsible of the DPPH radical scavenging activity. Thus, it is important to point out the contribution of the other compounds of PSEO in its scavenging capacity mainly pseudoisoeugenol which contains a hydroxyl group on its ring that probably acts as a hydrogen donator to stabilize the DPPH radical (Supplementary Fig. 1B). 


\subsubsection{The inhibition of $\beta$-carotene bleaching}

This test is based on the loss of the yellow color of $\beta$-carotene due to its reaction with conjugated diene hydroperoxides resulting from linoleic acid oxidation in the emulsion (Marco, 1968). This $\beta$-carotene bleaching is retarded in presence of antioxidants. As revealed in Fig. 1B, PSEO protected $\beta$-carotene from bleaching reaching $80 \%$ of inhibition at $700 \mu \mathrm{g} / \mathrm{mL}$ with an $\mathrm{IC}_{50}$ of $206 \mu \mathrm{g} / \mathrm{mL}$. In fact, it is known that nonpolar antioxidants display strong antioxidative properties in emulsions because they concentrate at the lipid/air surface allowing high protection of the emulsion itself (Frankel, Huang, Kanner, \& German, 1994). This explains the strong antioxidant activity exhibited by PSEO in the $\beta$-carotene/linoleic acid system. Previous studies recorded the capacity of the essential oils from Apiaceae family to protect $\beta$-carotene from bleaching like those of anise, dill $\left(60.91 \%\right.$ and $35.54 \%$ at $1 \mathrm{mg} / \mathrm{mL}$, respectively) and coriander $\left(\mathrm{IC}_{50}=230 \mu \mathrm{g} / \mathrm{mL}\right)$ (Duarte, Luís, Oleastro, \& Domingues, 2016; Nanasombat \& Wimuttigosol, 2011).

\subsubsection{Reducing power assay}

Fe (III) reduction can be used as an indicator of electron-donating activity which reflects an important mechanism of antioxidant action. As observed in Fig. 1C, the reducing power of PSEO and BHA increased in a concentration-dependent manner. PSEO displayed strong reducing potential $\left(\mathrm{EC}_{50}=35.20 \mu \mathrm{g} / \mathrm{mL}\right)$ as previously reported for P. anisum by Singh et al. (2008). The components present in the $P$. saxifraga and $P$. anisum essential oil could act as good reductants due to their electron donating capacity to transform $\mathrm{Fe}^{3+}$ to the ferrous form $\left(\mathrm{Fe}^{2+}\right)$ (Singh et al., 2008).

\subsubsection{Total antioxidant activity}

The antioxidant ability could be also determined by the reduction of $\mathrm{Mo}(\mathrm{VI})$ to $\mathrm{Mo}(\mathrm{V})$ and the subsequent formation of a green phosphate/Mo(V) complex at acidic media (Prieto, Pineda, \& Aguilar, 1999). As depicted in Fig. 1D, PSEO exhibited high total antioxidant activity that increased with concentration $(213.96 \pm 11.12 \mu \mathrm{mol} / \mathrm{mL} \alpha$-tocopherol equivalent at the concentration 
of $500 \mu \mathrm{g} / \mathrm{mL}$ ), while, the positive standard BHA did not exceed $160.23 \pm 0.06 \mu \mathrm{mol} / \mathrm{mL} \alpha$ tocopherol equivalent at the same concentration. Even at low concentrations, PSEO showed higher total antioxidant activity than BHA. The expression of the antioxidant capacity in terms of $\alpha$ tocopherol equivalent is based on the reducing potential of the hydroxyl group of the 6hydroxychroman ring involved in tocopherol structure (Prieto, Pineda, \& Aguilar, 1999). Thus, the hydroxyl group on the pseudoisoeugenol ring is probably the reason of the very strong total antioxidant activity of PSEO (Supplementary Fig. 1B).

\subsubsection{Oxidative DNA damage protective activity}

Damage of DNA in plasmids results in a cleavage of one of the phosphodiester chains of the supercoiled DNA and produces a relaxed open circular form. Further, cleavage near the first breakage results in linear double-stranded DNA molecules. The formation of circular form of DNA is indicative of single-strand breaks and the formation of linear form of DNA is indicative of double-strand breaks (Burrows \& Muller, 1998). In this study, oxidative DNA damage protective activity of PSEO was evaluated against $\mathrm{OH}^{*}$ induced damage on pGAP plasmid DNA. As shown in lane 2 (Fig. 1E and F), incubation of DNA with Fenton's reagent resulted in a complete degradation of DNA, indicating that $\mathrm{OH}^{\bullet}$ generated by Fenton's reagent produced multiple double-strand DNA breaks. Addition of PSEO at $0.625 \mathrm{mg} / \mathrm{mL}$ (lane 3) showed partial retention of supercoiled DNA (46\%) and mitigated the oxidative stress produced by Fenton's reagent. However, at 1.25 and 2.5 $\mathrm{mg} / \mathrm{mL}$ (lanes 4 and 5), the PSEO induced a significant reduction in the formation of open circular and increased the retention of the supercoiled form of plasmid DNA (88\% and 89\%, respectively). As previously depicted in the DPPH, $\beta$-carotene bleaching, reducing power and antioxidant activity assays, PSEO exhibited great potential to quench reactive oxygen species by donating hydrogen atom or electron. This type of action might prevent the free radicals-mediated oxidation of DNA through directly scavenging $\mathrm{OH}^{\bullet}$ and therefore protecting the supercoiled plasmid DNA from $\mathrm{OH}$ radicals. 
In this study, it has been shown that PSEO exhibited strong antioxidant activity through different mechanisms that could be used in various food and pharmaceutical applications to protect products from oxidation and enhance their health effects.

\subsection{Evaluation of the antibacterial activity of $P$. saxifraga essential oil}

Controlling bacterial infections has become a major problem due to the development of bacterial resistance against a large spectrum of commercial antibiotics. Thus, the research of new natural materials with antibacterial agents has recently expanded (Fair \& Tor, 2014). In this study, antibacterial activity of PSEO was assessed against three Gram- and three Gram+ bacteria. $S$. Typhimurium and $B$. cereus were the most sensitive strains to the PSEO (Inhibition zone diameter ID $=14$ and $14.5 \mathrm{~mm}$, respectively; Table 2). Our results are in accordance with those of Tepe et al. (2006) reporting that $P$. anisetum and $P$. flabellifoli had a moderate antibacterial activity against $B$. cereus and E. coli. However, B. cereus was more sensitive to PSEO (MIC $=1.56 \mathrm{mg} / \mathrm{mL})$ than to those of $P$. anisetum and $P$. flabellifoli $(\mathrm{MIC}=72 \mathrm{mg} / \mathrm{mL}$ for both species). In fact, PSEO exhibited a bactericide effect against $S$. Typhimurium, B. cereus and M. luteus (MBC/MIC < 4), while it showed only a bacteriostatic effect against $E$. coli, $P$. aeruginosa and L. monocytogenes (MBC/MIC > 4). According to Diao et al. (2014), anethole and its isomers are mainly responsible for the antimicrobial activity of the essential oils which contain them. Thus, the antibacterial activity of PSEO could be attributed to the presence of anethole. In general, the large number of essential oil components makes it difficult to attribute the antibacterial activity to one specific mechanism. Nevertheless, it has been demonstrated in several studies that one of the main antibacterial action mechanisms is related to the dissolution of essential oil components in the lipids of the bacterial cell membrane and mitochondria due to their lipophilic character. This disturbs cell membrane and induces ions leakage leading to cell death (Sikkema, de Bont, \& Poolman, 1994). 


\subsection{Acute toxicity study of $P$. saxifraga essential oil}

In the present study, acute toxicity is conducted to evaluate the safety of PSEO for a further food application. The acute toxicity was assessed in mice model by the observation of the animal behaviour after PSEO administration. All the observations are noted in Table 3. When PSEO was administrated to mice by intraperitoneal injection, doses of 250 and $500 \mathrm{mg} / \mathrm{kg}$ had no harmful effects on mice. In fact, the plants belonging to Pimpinella genius are known for their therapeutic properties and they are widely used in folk medicine. Superior doses induced abnormal behaviour in mice starting few minutes (5 to $10 \mathrm{~min}$ ) after the injection like fast breathing and hypoactivity for groups administrated with 750 and $1000 \mathrm{mg} / \mathrm{kg}$. Death was lately recorded for some mice but the survived ones were completely recovered and gradually resumed normal activity. In addition to fast breathing and hypoactivity, high doses of PSEO such as 1500 and $3500 \mathrm{mg} / \mathrm{kg}$ lead to loss of consciousness followed by death ( 85 and $100 \%$ dead animals, respectively). The estimated $\mathrm{LD}_{50}$ by linear regression of the dose-response curve was $976.2 \mathrm{mg} / \mathrm{kg}$ (Supplementary Fig. 2). The $\mathrm{LD}_{50}$ is crucial for the prediction of the symptomatology of poisoning after acute overdosing in humans (Hilan et al., 2009). It was demonstrated that intraperitoneal $\mathrm{LD}_{50}$ values for anethole, major compound in PSEO, were ranged between 650 and $1410 \mathrm{mg} / \mathrm{kg}$ in mice. In fact, it has been previously showed that the essential oil of $P$. anisum, mainly composed of anethole exhibited anticonvulsant and neuroprotective effects. However, its excessive administration could induce disturbance in motor coordination (Pourgholami et al., 1999). Although the toxicity of essential oils is influenced by several factors like species, strain, environment and processing, it is important to assess toxicological tests including the $\mathrm{LD}_{50}$ determination before any application of essential oils.

\subsection{Cheese preservation by alginate coating containing $P$. saxifraga essential oil}

It is known that uncoated fresh cheese including "Béja Sicilian cheese" is very sensitive to microbial contamination and lipid peroxidation leading to quality deterioration. In this case, cheese 
edible coating could be a solution to preserve its nutritional and organoleptic properties during storage. In this work, the effect of sodium alginate coating enriched with PSEO on "Béja Sicilian cheese" preservation was studied by the evaluation of weight loss, $\mathrm{pH}$, water activity, color and oxidative and microbial stability. Furthermore, a sensorial analysis was conducted to evaluate the acceptance of the coated cheese by consumers.

\subsubsection{Evaluation of weight loss}

For all coated and uncoated samples, the loss of weight was measured at 4, 7 and 10 days of storage at $4{ }^{\circ} \mathrm{C}$. As observed in Fig. 2A, the weight loss increased during chilled storage time in all cheese samples. This is possibly due to the phenomena of whey exudation during storage leading to continuous moisture migration from cheese to surrounding environment (Samal, Pearce, Bennett, \& Dunlop, 1993). In fact, the uncoated control sample weight loss reached $9.7 \%, 17.3 \%$ and $23.4 \%$ after 4, 7 and 10 days of storage, respectively. However, SA coating allowed the reduction of the weight loss to of $6.7 \%, 9.9 \%$ and $14.9 \%$ at 4,7 and 10 days, respectively. The study of Cerqueira et al. (2010) showed that galactomannans coatings reduced the weight loss (about 20\%) of the cheese by $3.8 \%$ during storage at $4{ }^{\circ} \mathrm{C}$. The effect of $k$-carrageenan and alginate coating on the decrease in weight loss of semi-soft cheese was also shown by Kampf \& Nussinovitch (2000). It is known that sodium alginate, a marine linear polysaccharide, has a good moisture-retention ability especially in cheese where guluronic residues bind to $\mathrm{Ca}^{2+}$ ions to form an egg-box structure which act like a barrier (Costa et al., 2018). The addition of PSEO to the SA coating showed an important decrease of weight loss. A $3 \%$ of PSEO reduced the weight loss to $4.3 \%, 7.1 \%$ and $10 \%$ at 4,7 and 10 days, respectively. In general, the incorporation of hydrophobic essential oils into hydrophilic polymer matrices could enhance their barrier properties against water transfer (Ju et al., 2018). 


\subsubsection{Evaluation of $\mathrm{pH}$, water activity and color}

The $\mathrm{pH}$, water activity and color were evaluated at the beginning (day 1) and the end of the storage period (day 1 and day 10) (Table 4A). During chilled storage, the $\mathrm{pH}$ decreased in all samples and this is probably due to the presence of lactic bacteria involved in lactose fermentation leading to the cheese acidification. Free fatty acids generated by lipid peroxidation of cheese during storage could also contribute to its acidification (Di Pierro, Sorrentino, Mariniello, Giosafatto, \& Porta, 2011). However, the SA coating reduced significantly $(p<0.05)$ the cheese acidification especially in the presence of 3\% PSEO where pH varied only from 6.17 at day 1 to 5.92 at day 10 . This is probably due to antibacterial activity of PSEO which slowed down the development of lactic bacteria, and consequently reduced the acidification.

Water activity $\left(\mathrm{a}_{\mathrm{w}}\right)$ is defined as the amount of free water present in a product and available for bacterial growth. After 10 days of storage, the $a_{w}$ increased in all samples due to whey exudation. Since the coating represents a barrier against moisture loss, the $\mathrm{a}_{\mathrm{w}}$ of the coated cheese was significantly $(p<0.05)$ lower than that of the uncoated cheese. The presence of PSEO in the sodium alginate didn't have an effect on $\mathrm{a}_{\mathrm{w}}(p>0.05)$.

Moreover, the SA coating had obvious impact on color changes of the cheese as it described in Table 4A. The coating slightly increased the lightness of cheese (84.64-86.78) in comparison to the uncoated cheese (83.14) (Table 4A). During the storage, a decrease of L* to 80.99 in uncoated cheese was observed. It was less important in coated cheese especially in presence of PSEO (86.55 in presence of $3 \%$ PSEO). The decrease of $\mathrm{L}^{*}$ was attributed to microbial growth on the cheese surface (Bermúdez-Aguirre \& Barbosa-Cánovas, 2010). Since coating and PSEO reduced the microbial growth in cheese, they allowed to preserve its lightness. Unlike the uncoated cheese, the $\mathrm{a}^{*}$ and $\mathrm{b}^{*}$ values varied slightly within 10 days of chilled storage of coated cheese in presence of essential oil which prove that this active coating preserved the color of the cheese. 


\subsubsection{Microbial analysis of cheese}

Evolution of microbial population in cheese samples during chilled storage period was investigated (Table 4B). On the first day of storage, the mesophilic bacteria count was $3.89 \log$ $\mathrm{CFU} / \mathrm{g}$ while lactic bacteria count was $3.27 \mathrm{log} \mathrm{CFU} / \mathrm{g}$ probably due to the use of pasteurized milk and hygienic manipulation during cheese industrial production. During storage, the mesophilic bacteria of all samples increased reaching maximal levels at day 10 (5.66 CFU/g of uncoated cheese). The coated cheese showed lower mesophilic bacteria counts than those of uncoated cheese especially. The presence of 3\% PSEO in SA coating reduced the proliferation of mesophilic bacteria from 5.44 to $4.03 \log \mathrm{CFU} / \mathrm{g}$ at day 7 of chilled storage. These results are in agreement with the study of Cerqueira et al. (2010) showing that galactomannan coating limited growth of mesophilic bacteria in cheese (from 5.9 to $5.2 \log \mathrm{CFU} / \mathrm{g}$ at day 14). In fact, the coating reduces the transfer of gases $\left(\mathrm{O}_{2}\right.$ and $\left.\mathrm{CO}_{2}\right)$ to the cheese and the oxygen becomes less available for microbial growth (Cerqueira et al., 2010). Likewise, coating reduced the proliferation of the lactic bacteria, especially in presence of $3 \%$ PSEO, from 4.07 to $3.33 \log$ CFU/g at day 7. These results are in agreement with those of Martins, Cerqueira, Souza, Carmo Avides, \& Vicente (2010) showing that the addition of an antimicrobial agent to the galactomannan coating of ricotta cheese reduced the proliferation of Listeria monocytogenes by $2.2 \log \mathrm{CFU} / \mathrm{g}$ in comparison with the uncoated cheese. Coatings enriched with essential oils of oregano and pepper have also been applied in the preservation of beef to improve its microbial stability (Oussalah et al., 2004). These results showed the efficiency of the addition of the essential oil in edible coating as a natural antibacterial agent.

\subsubsection{Oxidative stability of cheese}

Lipid peroxidation is a spontaneous phenomenon involved in nutritional and organoleptic quality deterioration and food shelf-life reduction. Lipid peroxidation was evaluated during cheese storage at $4{ }^{\circ} \mathrm{C}$ by measuring TBARS ( $\mu \mathrm{g}$ of malondialdehyde (MDA) per $100 \mathrm{~g}$ of cheese) (Fig. 
2B). The MDA amount increased during the storage time from $19.5 \mu \mathrm{g}$ MDA/100 g at day 4 to $43.7 \mu \mathrm{g}$ MDA/100 $\mathrm{g}$ at day 10 in the uncoated cheese while it didn't exceed $34 \mu \mathrm{g}$ MDA/100 $\mathrm{g}$ in the SA coated cheese. It has been demonstrated that SA is endued with antioxidant activity and it could act as barrier to oxygen, which is one of the most important factors of peroxidation (Sellimi et al., 2015). The addition of essential oil in the SA coating contributed significantly to the decrease of the lipid oxidation $(p<0.05)$ (Fig. 2B). A concentration of $2 \%$ of PSEO had similar effect on the decrease of lipid peroxidation to the vitamin $\mathrm{C}$ added to SA coating (15.96 and 16.24 $\mu \mathrm{g}$ MDA/100 g, respectively at 10 days of storage). The cheese coated with SA enriched with $3 \%$ of PSEO presented the lowest MDA values $(8.5,10.5$ and $11.7 \mu \mathrm{g}$ MDA/100 $\mathrm{g}$ at 4,7 and 10 days of storage). In fact, in all cases, the addition of PSEO allowed to slow down the peroxidation since it was no significant increase of MDA amounts $(p>0.05)$ between 7 and 10 days of storage (Fig. 2B). The efficiency of the PSEO against cheese peroxidation confirms the results found above in the invitro tests of antioxidant activity that demonstrated its strong capacity in quenching and stabilizing free radicals, generated by lipid peroxidation in this case. The effect of essential oils incorporated in edible coatings on lipid peroxidation reduction of many products containing a high amount of fats (such as meat) has been previously described. For instance, Vital et al. (2016) showed that alginate coatings enriched with essential oils of oregano and rosemary reduced the lipid peroxidation of beef by $47 \%$ and $39 \%$, respectively.

\subsubsection{Sensory evaluation of cheese}

The sensory evaluation is very important when testing new active edible coatings in order to predict the acceptability of the coated product by the consumer. In our study, sensory analysis was conducted by a panel of 21 subjects to evaluate the effect of SA coating enriched with PSEO on the cheese. Overall acceptability average scores ranged from 2.57 to 4 in the 5-point Hedonic scale (Fig. 2C). In general the coated cheese was more appreciated than the uncoated cheese. The coated cheese with SA enriched with 3\% of PSEO was the most appreciated in terms of odor and flavor 
where it scored the highest average acceptability (3.71 and 3.42, respectively). This is probably due to the important presence of anethole, which is widely used as sweet flavoring agent and scent in food like candy, chewing gum and cigarettes (Marinov \& Valcheva-Kuzmanova, 2015). The coated samples with SA enriched with PSEO were the most appreciated in terms of color and aspect whatever the PSEO concentration was. This is in accordance with color analysis showing the high lightness of these samples. The panel subjects noted that texture was slightly enhanced with an average score of 3.57 for coated cheese and 3.42 in control. However, they did not detect any texture difference between coated cheese with SA and cheese coated with SA enriched with PSEO.

\section{Conclusion}

The essential oil of $P$. saxifraga (PSEO), as a novel natural bioactive compound, was successfully incorporated in sodium alginate coating for cheese preservation. PSEO, mainly composed of anethole, exhibited potent antioxidant and antibacterial abilities. The addition of PSEO (1-3\%) in sodium alginate coating (2\% sodium alginate $+15 \%$ glycerol) was effective in reducing the weight loss, preserving $\mathrm{pH}$ and color and improving the oxidative and bacterial stability of the coated cheese. The sensory analysis showed high appreciation of coated cheese in presence of PSEO. For the prediction of the symptomatology of poisoning after acute overdosing in humans, the acute toxicity of PSEO was determined using a mice model $\left(\mathrm{LD}_{50}=976.2 \mathrm{mg} / \mathrm{kg}\right)$. 


\section{Acknowledgment}

This work was financially supported by the "PHC Utique" program of the Tunisian Ministry of higher education and scientific research and the French Ministry of Foreign Affairs and Ministry of higher education and research and the in the CMCU project number 16G/0912. This study was also supported by the Regional Council of Picardie and European Union co-founded equipment utilized within CPER 2007-2020.

Declarations of interest: none 


\section{References}

Abid, M., Yaich, H., Hidouri, H., Attia, H., \& Ayadi, M. A. (2018). Effect of substituted gelling agents from pomegranate peel on colour, textural and sensory properties of pomegranate jam. Food Chemistry, 239, 1047-1054.

Adorjan, B., \& Buchbauer, G. (2010). Biological properties of essential oils: An updated review. Flavour and Fragrance Journal, 25(6), 407-426.

Andrews, J. M. (2001). Determination of minimum inhibitory concentrations. The Journal of Antimicrobial Chemotherapy, 48, 5-16.

Arslan, N., Gürbüz, B., Sarihan, E. O., Bayrak, A., \& Gümüşçü, A. (2004). Variation in essential oil content and composition in Turkish anise (Pimpinella anisum L.) populations. Turkish Journal of Agriculture and Forestry, 28(3), 173-177.

Augustyniak, A., Bartosz, G., Čipak, A., Duburs, G., Horáková, L., Łuczaj, W., Majekova, M., Odysseos, A., Rackova, L., Skrzydlewska, L. \& Žarković, N. (2010). Natural and synthetic antioxidants: An updated overview. Free Radical Research, 44(10), 1216-1262.

Berghe, V. A., \& Vlietinck, A. J. (2011). Screening methods for antibacterial and antiviral agents from higher plants. In Methods for plant biochemistry (pp. 47-68).

Bermúdez-Aguirre, D., \& Barbosa-Cánovas, G. V. (2010). Processing of Soft Hispanic Cheese ("Queso Fresco") Using Thermo-Sonicated Milk: A Study of Physicochemical Characteristics and Storage Life. Journal of Food Science, 75(9), S548-S558.

Bersuder, P., Hole, M., \& Smith, G. (1998). Antioxidants from a heated histidine-glucose model system. I: Investigation of the antioxidant role of histidine and isolation of antioxidants by high-performance liquid chromatography. Journal of the American Oil Chemists' Society, 75(2), 181-187.

Buege, J. A., \& Aust, S. D. (1978). Microsomal lipid peroxidation. Methods in Enzymology, 52, 302-310.

Burrows, C. J., \& Muller, J. G. (1998). Oxidative Nucleobase Modifications Leading to Strand Scission. Chemical Reviews, 98(3), 1109-1152.

Burt, S. (2004). Essential oils: their antibacterial properties and potential applications in foods-a review. International Journal of Food Microbiology, 94, 223-253.

Cerqueira, M. A., Sousa-Gallagher, M. J., Macedo, I., Rodriguez-Aguilera, R., Souza, B. W. S., Teixeira, J. A., \& Vicente, A. A. (2010). Use of galactomannan edible coating application and storage temperature for prolonging shelf-life of "Regional" cheese. Journal of Food Engineering, 97(1), 87-94.

Costa, M. J., Marques, A. M., Pastrana, L. M., Teixeira, J. A., Sillankorva, S. M., \& Cerqueira, M. A. (2018). Physicochemical properties of alginate-based films: Effect of ionic crosslinking and mannuronic and guluronic acid ratio. Food Hydrocolloids, 81, 442-448.

Di Pierro, P., Sorrentino, A., Mariniello, L., Giosafatto, C. V. L., \& Porta, R. (2011). Chitosan/whey protein film as active coating to extend Ricotta cheese shelf-life. LWT - Food Science and Technology, 44(10), 2324-2327. 
Diao, W. R., Hu, Q. P., Zhang, H., \& Xu, J. G. (2014). Chemical composition, antibacterial activity and mechanism of action of essential oil from seeds of fennel (Foeniculum vulgare Mill.). Food Control, 35(1), 109-116.

Duarte, A., Luís, Â., Oleastro, M., \& Domingues, F. C. (2016). Antioxidant properties of coriander essential oil and linalool and their potential to control Campylobacter spp. Food Control, 61, $115-122$

Fair, R. J., \& Tor, Y. (2014). Antibiotics and Bacterial Resistance in the $21^{\text {st }}$ Century. Perspectives in Medicinal Chemistry, 6, PMC.S14459.

Frankel, E. N., Huang, S.-W., Kanner, J., \& German, J. B. (1994). Interfacial Phenomena in the Evaluation of Antioxidants: Bulk Oils vs Emulsions. Journal of Agricultural and Food Chemistry, 42(5), 1054-1059.

Freire, R. S., Morais, S. M., Catunda, F. E. A., \& Pinheiro, D. C. S. N. (2005). Synthesis and antioxidant, anti-inflammatory and gastroprotector activities of anethole and related compounds. Bioorganic and Medicinal Chemistry, 13(13), 4353-4358.

Grys, A., Komorowska, E. W. A., Mielcarek, S., Łowicki, Z., Latowski, K., \& Buchwald, W. (2009). Evaluation of the analytical method for a chromatographic profile assessment of the essential oil obtained from Pimpinella saxifraga s .1. Herba Polonica, 55(3), 109-117.

Gulfraz, M., Mehmood, S., Minhas, N., Jabeen, N., Kausar, R., Jabeen, K., \& Arshad, G. (2008). Composition and antimicrobial properties of essential oil of Foeniculum vulgare. African Journal of Biotechnology, 7(24), 4364-4368.

Hilan, C., Bouaoun, D., Aoun, J., Sfeir, R., \& Garabeth, F. (2009). Propriétés antimicrobiennes et toxicité par détermination de la DL50 de l'huile essentielle de Prangos asperula Boissier. Phytotherapie, 7(1), 8-14.

Ju, J., Xie, Y., Guo, Y., Cheng, Y., Qian, H., \& Yao, W. (2018). Application of edible coating with essential oil in food preservation. Critical Reviews in Food Science and Nutrition.

Kampf, N., \& Nussinovitch, A. (2000). Hydrocolloid coating of cheeses. Food Hydrocolloids, $14(6), 531-537$.

Khalil, N., Ashour, M., Fikry, S., Singab, A., \& Salama, O. (2017). Chemical composition and antimicrobial activity of the essential oils of selected Apiaceous fruits. Future Journal of Pharmaceutical Sciences Journal, 1-5.

Lee, J. C., Kim, H. R., Kim, J., \& Jang, Y. S. (2002). Antioxidant property of an ethanol extract of the stem of Opuntia ficus-indica var. saboten. Journal of Agricultural and Food Chemistry, 50(22), 6490-6496.

Lo Cantore, P., Iacobellis, N. S., De Marco, A., Capasso, F., \& Senatore, F. (2004). Antibacterial Activity of Coriandrum sativum L. and Foeniculum vulgare Miller Var. vulgare (Miller) Essential oils. Journal of Agricultural and Food Chemistry, 52(26),

Marco, G. J. (1968). A rapid method for evaluation of antioxidants. Journal of the American Oil Chemists' Society, 45(9), 594-598.

Marinov, V., \& Valcheva-Kuzmanova, S. (2015). Review on the pharmacological activities of 
anethole. Scripta Scientifica Pharmaceutica, 2(2), 14-19.

Martins, J. T., Cerqueira, M. A., Souza, B. W. S., Carmo Avides, M. do, \& Vicente, A. A. (2010). Shelf Life Extension of Ricotta Cheese Using Coatings of Galactomannans from Nonconventional Sources Incorporating Nisin against Listeria monocytogenes. Journal of Agricultural and Food Chemistry, 58(3), 1884-1891.

Masoudi, S., Rustaiyan, A., \& Mazloomifar, H. (2009). Composition of the Essential Oils of Pimpinella anisactis Rech.f. and Pimpinella saxifraga L. from Iran. Journal of Essential Oil Research, 21(2), 146-148.

Nanasombat, S., \& Wimuttigosol, P. (2011). Antimicrobial and antioxidant activity of spice essential oils. Food Science and Biotechnology, 20(1), 45-53.

Pourgholami, M. ., Majzoob, S., Javadi, M., Kamalinejad, M., Fanaee, G. H., \& Sayyah, M. (1999). The fruit essential oil of Pimpinella anisum exerts anticonvulsant effects in mice. Journal of Ethnopharmacology, 66(2), 211-215.

Prieto, P., Pineda, M., \& Aguilar, M. (1999). Spectrophotometric quantitation of antioxidant capacity through the formation of a phosphomolybdinum complex: specific application to the determination of Vitamin E. Analytical Biochemistry, 269, 337-341.

Reichling, J., \& Rainer, M. (1990). Further Studies on the Biosynthesis of Pseudoisoeugenols in Tissue Cultures of Pimpinella anisum. Verlag Der Zeitschrift Für Naturforschung, 45c, 942948.

Samal, P. K., Pearce, K. N., Bennett, R. J., \& Dunlop, F. P. (1993). Influence of residual rennet and proteolysis on the exudation of whey from Feta cheese during storage. International Dairy Journal, 3(8), 729-745.

Sangwan, N. S., Farooqi, A. H. A., Shabih, F., \& Sangwan, R. S. (2001). Regulation of essential oil production in plants. Plant Growth Regulation, 34(1), 3-21.

Santos, P. M., Figueiredo, A. C., Oliveira, M. M., Barroso, J. G., Pedro, L. G., Deans, S. G., \& Scheffer, J. J. C. (1998). Essential oils from hairy root cultures and from fruits and roots of Pimpinella anisum. Phytochemistry, 48(3), 455-460.

Sellimi, S., Younes, I., Ayed, H. Ben, Maalej, H., Montero, V., Rinaudo, M., Mostefa, D., Mechichi, T., Hajji, M., \& Nasri, M. (2015). Structural, physicochemical and antioxidant properties of sodium alginate isolated from a Tunisian brown seaweed. International Journal of Biological Macromolecules, 72, 1358-1367.

Sikkema, J., de Bont, J. A., \& Poolman, B. (1994). Interactions of cyclic hydrocarbons with biological membranes. The Journal of Biological Chemistry, 269(11), 8022-8028.

Singh, G., Kapoor, I., Singh, P., Heluani, C., \& Catalan, C. (2008). Chemical composition and antioxidant potential of essential oil and oleoresins from anise seeds (Pimpinella anisum L.). International Journal of Essential Oil Therapeutics, 122-130.

Singh, G., Maurya, S., Lampasona, M. P., \& Catalan, C. (2005). Chemical constituents, antimicrobial investigations, and antioxidative potentials of Anethum graveolens L. essential oil and acetone extract: Part 52. Journal of Food Science, 70(4), 208-215. 
Tavassoli-Kafrani, E., Shekarchizadeh, H., \& Masoudpour-Behabadi, M. (2016). Development of edible films and coatings from alginates and carrageenans. Carbohydrate Polymers, 137, 360374.

Tepe, B., Akpulat, H. A., Sokmen, M., Daferera, D., Yumrutas, O., Aydin, E., Pollisou, M., \& Sokmen, A. (2006). Screening of the antioxidative and antimicrobial properties of the essential oils of Pimpinella anisetum and Pimpinella flabellifolia from Turkey. Food Chemistry, 97(4), 719-724.

The European Parliament and the Council of the European union. (2010). DIRECTIVE 2010/63/EU on the protection of animals used for scientific purposes. Official Journal of the European Union.

Tisserand, R., \& Young, R. (2013). Essential oil safety: a guide for health care professionals. Elsevier. Edinburgh: Churchill Livingstone, p. 795.

Valgas, C., Souza, S. M. de, Smânia, E. F. A., \& Smânia Jr., A. (2007). Screening methods to determine antibacterial activity of natural products. Brazilian Journal of Microbiology, 38(2), 369-380.

Vital, A. C. P., Guerrero, A., Monteschio, J. de O., Valero, M. V., Carvalho, C. B., De Abreu Filho, B. A., Madrona, G., \& Do Prado, I. N. (2016). Effect of Edible and Active Coating (with Rosemary and Oregano Essential Oils) on Beef Characteristics and Consumer Acceptability. PLOS ONE, 11(8), e0160535.

Yildirim, A., Mavi, A., \& Kara, A. A. (2001). Determination of antioxidant and antimicrobial activities of Rumex crispus L. extracts. Journal of Agricultural and Food Chemistry, 49(8), 4083-4089. 


\section{Figure captions:}

Figure 1. Antioxidant activity of PSEO: (A) DPPH radical scavenging capacity, (B) Inhibition of $\beta$ carotene bleaching assay, (C) Reducing power assay, (D) Total antioxidant activity, BHA : synthetic commercial antioxidant used as positive control (E) Gel electrophoresis pattern of pGap DNA incubated with Fenton's reagent in the presence and absence of PSEO; Lane 1: native DNA, lane 2: DNA incubated with Fenton's reagent; lanes 3, 4 and 5 represent DNA + Fenton's reagent + essential oil of $P$. saxifraga at different concentrations $(0.625,1.25$ and $2.5 \mathrm{mg} / \mathrm{mL}$, respectively) a: Nicked circular form; b: Supercoiled form, (F) Retention of supercoiled DNA (\%).

Figure 2. Evaluation of the weight loss, $\mathrm{pH}$, water activity, oxidative and bacterial stability and consumer acceptability of cheese (A) Weight loss of cheese samples (\%) at 4, 7 and 10 days of storage at $4{ }^{\circ} \mathrm{C},(\mathrm{B})$ Lipid peroxidation ( $\mu \mathrm{g}$ MDA/100 $\mathrm{g}$ cheese) of cheese samples evaluated at 1,4 , 7 and 10 days of storage at $4{ }^{\circ} \mathrm{C}$, (C) Radar chart representing mean scores of the sensory evaluation of cheese samples after $24 \mathrm{~h}$ of storage at $4{ }^{\circ} \mathrm{C}$. Control: uncoated cheese; SA: Cheese coated with only sodium alginate solution, SA $+1 \%$ PSEO: Cheese coated with sodium alginate solution containing 1\% PSEO; SA $+2 \%$ PSEO: Cheese coated with sodium alginate solution containing 2\% PSEO; SA + 3\% PSEO: Cheese coated with sodium alginate solution containing 3\% PSEO; SA + Vit C: Cheese coated with sodium alginate solution containing $1 \%$ of vitamin C. (a-c) Different subscripts indicate significant differences for the same sample within different days of storage $(p<0.05)$. (A-D) Different letters indicate significant differences between samples in the same storage day

$(p$ $0.05)$. 
Fig. 1
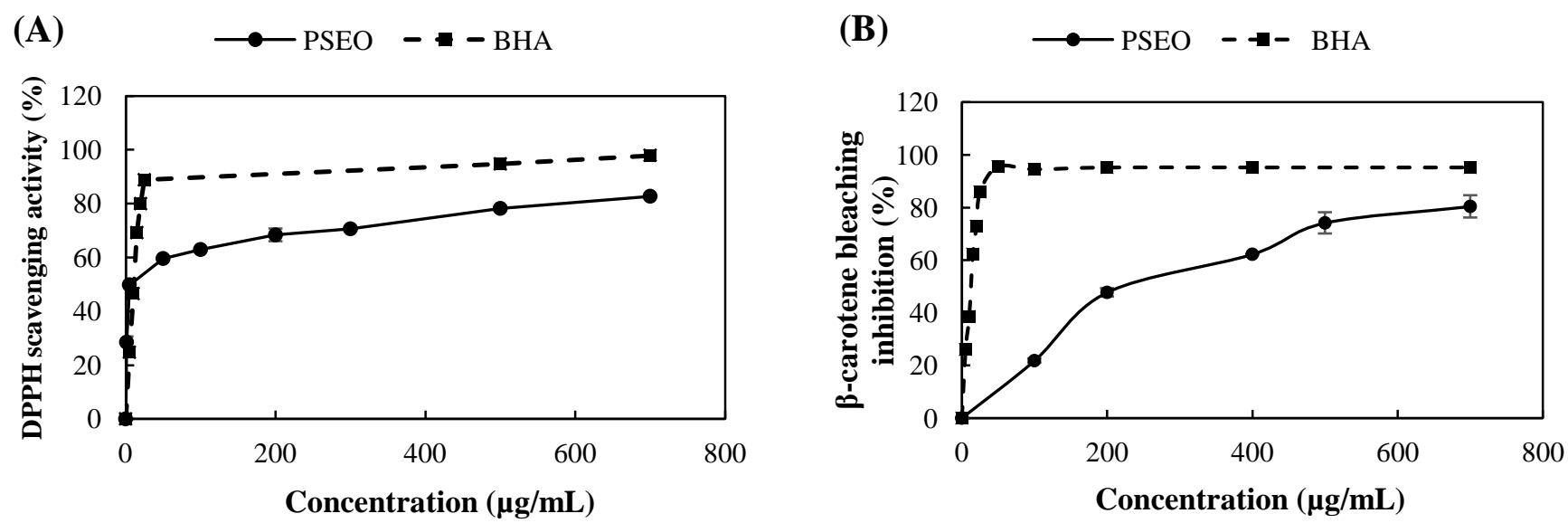

(C) $\longrightarrow$ PSEO -- BHA

(D)
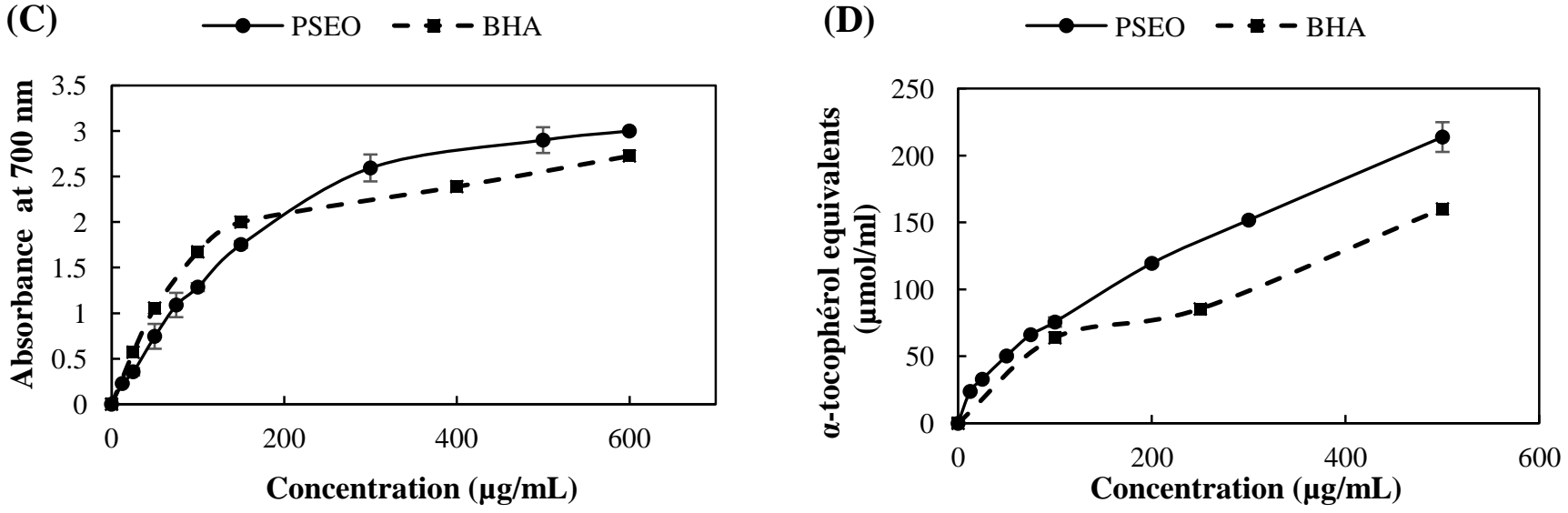

(E)

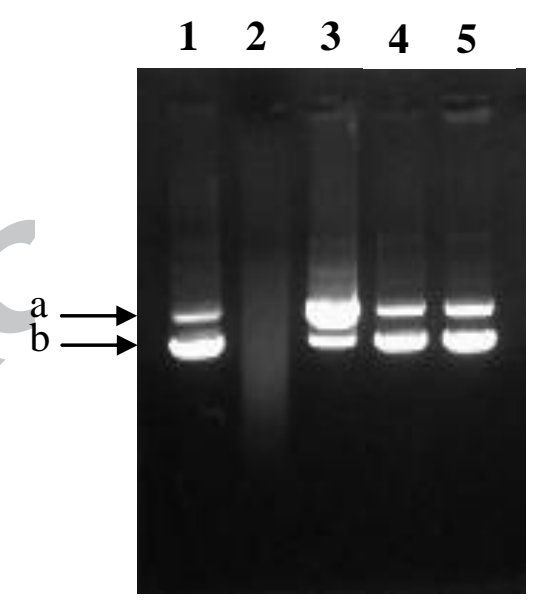

(F)

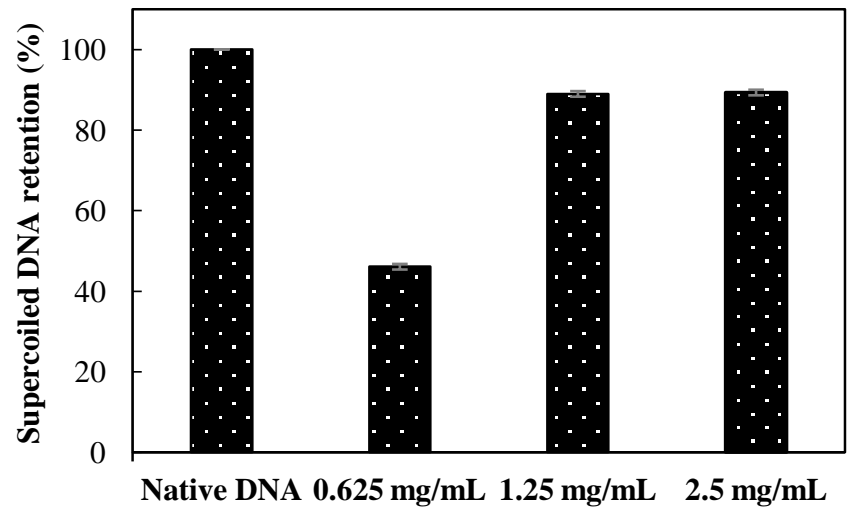


Fig. 2
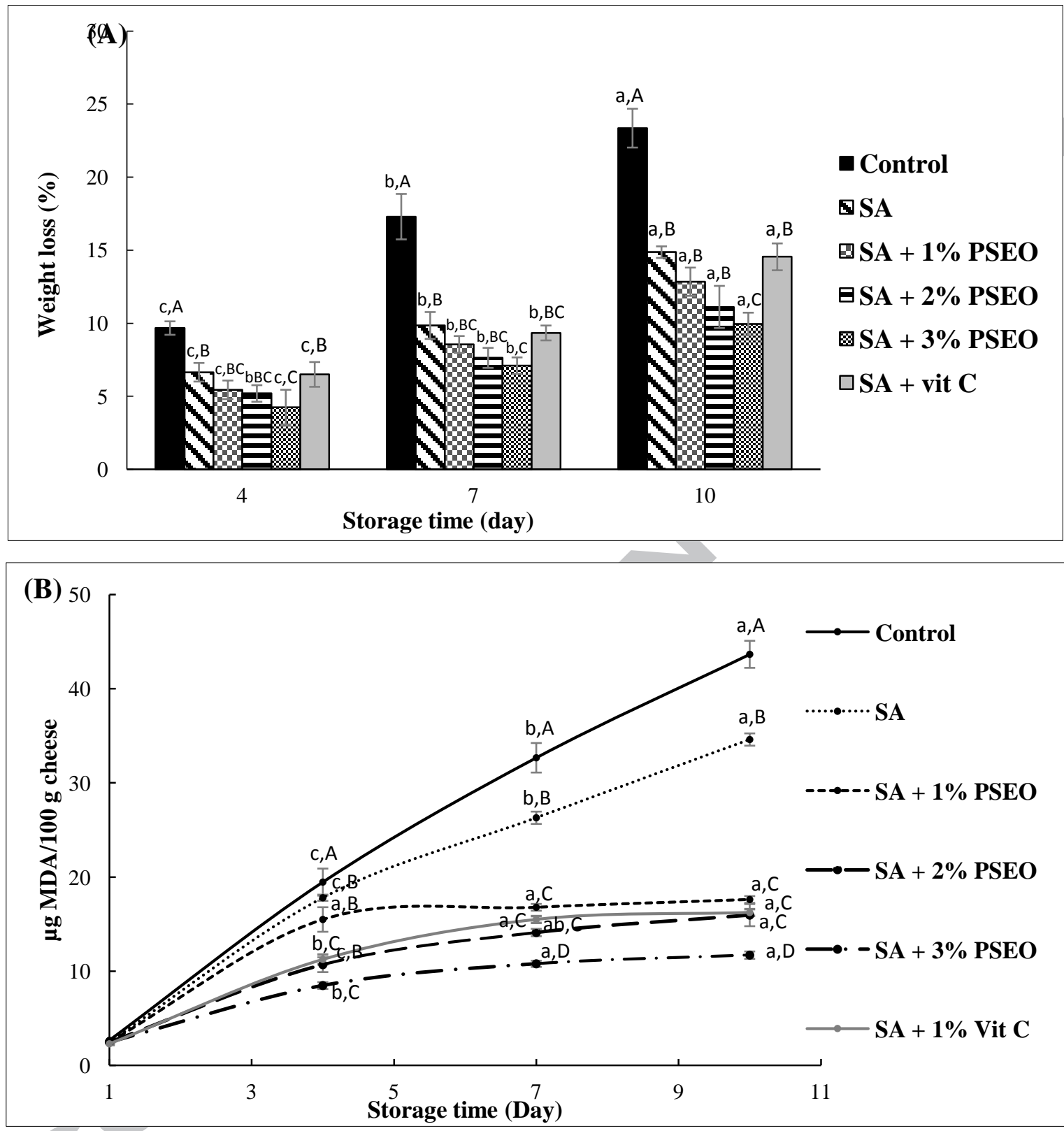


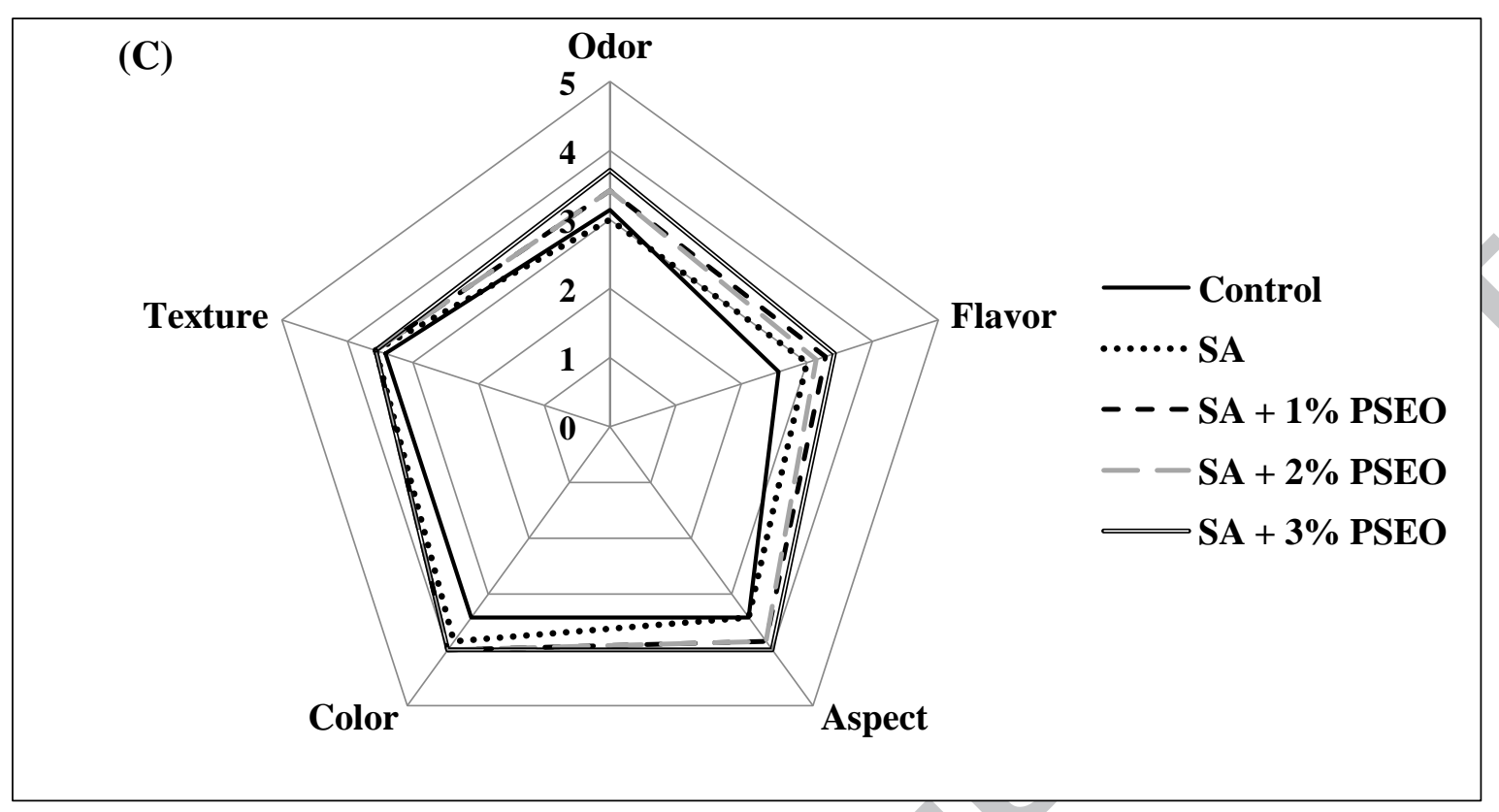


Table 1: Chemical composition of the essential oil of $P$. saxifraga.

\begin{tabular}{lcc}
\hline Component & Retention index & $\begin{array}{c}\text { \% of total volatil } \\
\text { compounds }\end{array}$ \\
\hline$p$-Anisaldehyde & 1245 & 7.53 \\
Anethole & 1282 & 59.47 \\
2-Ethyl-4,5-dimethylphenol & 1309 & 0.10 \\
Acetanisole & 1346 & 0.09 \\
Anisketone & 1377 & 1.71 \\
Methyl $o$-coumarate & 1429 & 0.25 \\
Thujpsadiene & 1469 & 0.22 \\
4,11-selinadiene & 1486 & 2.99 \\
1-(2-Hydroxy-4-methoxyphenyl)propan-1-one & 1542 & 0.49 \\
4-methoxycinnamaldehyde & 1556 & 0.09 \\
Dillapiole & 1605 & 0.51 \\
1-Calamenene & 1663 & 0.10 \\
$\beta$-Selinene & 1682 & 0.13 \\
Pseudoisoeugenol & 1833 & 20.15 \\
Thellungianin G & 1884 & 6.17 \\
\hline Total & & $100 \%$ \\
\hline \% of identified compounds & & 93.5 \\
\hline Number of identified compounds & 15 \\
\hline
\end{tabular}

Table 2: Evaluation of antibacterial activity of $P$. saxifraga essential oil.

\begin{tabular}{|c|c|c|c|c|}
\hline \multirow[b]{2}{*}{ Bacteria } & \multicolumn{2}{|c|}{ Diameter of the inhibition zone ID $(\mathrm{mm} \pm \mathrm{SD})$} & \multirow{2}{*}{$\begin{array}{c}\text { MIC } \\
(\mathbf{m g} / \mathbf{m L})\end{array}$} & \multirow{2}{*}{$\begin{array}{c}\text { MBC } \\
(\mathbf{m g} / \mathbf{m L})\end{array}$} \\
\hline & Gentamycin & $P$. saxifraga essential oil & & \\
\hline \multicolumn{5}{|l|}{ Gram- } \\
\hline E. coli & 15 & $7.5 \pm 0.2$ & 0.78 & 3.125 \\
\hline S. Typhimurium & 18 & $14.5 \pm 0.8$ & 3.125 & 6.25 \\
\hline P. aeruginosa & 18 & $11 \pm 0.3$ & 1.56 & 6.25 \\
\hline \multicolumn{5}{|l|}{ Gram + } \\
\hline B. cereus & 22 & $14 \pm 0.7$ & 1.56 & 3.125 \\
\hline M. luteus & 18 & $11 \pm 0.3$ & 3.125 & 6.25 \\
\hline L. monocytogenes & 15 & $7.25 \pm 0.25$ & 1.56 & 12.5 \\
\hline
\end{tabular}

MIC and MBC were minimal inhibitory concentration and minimal bactericidal concentration, respectively. SD: Standard deviation 
Table 3: Study of acute toxicity of $P$. saxifraga essential oil

\begin{tabular}{cccl}
\hline $\begin{array}{c}\text { Dose } \\
(\mathbf{m g} / \mathbf{k g})\end{array}$ & $\begin{array}{c}\text { Number of } \\
\text { dead mice }\end{array}$ & $\begin{array}{c}\text { Mortality } \\
\text { rate }(\boldsymbol{\%})\end{array}$ & \multicolumn{1}{c}{ Symptoms } \\
\hline $\mathbf{2 5 0}$ & 0 & 0 & nd \\
\hline $\mathbf{5 0 0}$ & 0 & 0 & nd \\
\hline $\mathbf{7 5 0}$ & 2 & 25 & $\begin{array}{l}\text { Fast breathing, hypoactivity, death after 14 hours and total } \\
\text { recovery of the survived mice. }\end{array}$ \\
\hline $\mathbf{1 0 0 0}$ & 6 & 75 & $\begin{array}{l}\text { Fast breathing, hypoactivity, death after } 12 \text { hours and total } \\
\text { recovery of the survived mice. }\end{array}$ \\
\hline $\mathbf{1 5 0 0}$ & 7 & 87.5 & $\begin{array}{l}\text { Fast breathing, hypoactivity, groaning, unconsciousness, } \\
\text { death after } 30 \pm 9 \text { min and total recovery of the survived } \\
\text { mice. }\end{array}$ \\
\hline $\mathbf{3 5 0 0}$ & 8 & 100 & $\begin{array}{l}\text { Fast breathing, hypoactivity, groaning, unconsciousness, } \\
\text { death after 20 } \pm 5 \text { min. }\end{array}$ \\
\hline
\end{tabular}

nd: not defined 
Table 4A: $\mathrm{pH}$ and $\mathrm{a}_{\mathrm{w}}$ measurements at 1, 4 and 10 days of storage and change of color between 1 and 10 days of storage at $4{ }^{\circ} \mathrm{C}$

\begin{tabular}{|c|c|c|c|c|c|c|c|}
\hline & & Control & SA & SA + 1\% PSEO & SA + $2 \%$ PSEO & SA + 3\% PSEO & $\mathrm{SA}+\operatorname{vit} \mathrm{C}$ \\
\hline \multirow{2}{*}{ pH } & Day 1 & $6.31 \pm 0.01^{\mathrm{A}}$ & $6.26 \pm 0.00^{\mathrm{A}}$ & $6.17 \pm 0.00^{\mathrm{B}}$ & $6.16 \pm 0.00^{\mathrm{B}}$ & $6.17 \pm 0.00^{\mathrm{B}}$ & $6.12 \pm 0.02^{\mathrm{C}}$ \\
\hline & Day 10 & $5.78 \pm 0.01^{\mathrm{C}}$ & $5.93 \pm 0.00^{\mathrm{A}}$ & $5.88 \pm 0.01^{\mathrm{B}}$ & $5.89 \pm 0.00^{\mathrm{B}}$ & $5.92 \pm 0.02^{\mathrm{A}}$ & $5.71 \pm 0.01^{\mathrm{D}}$ \\
\hline \multirow{2}{*}{$\mathbf{a}_{\mathbf{w}}$} & Day 1 & $0.909 \pm 0.00^{\mathrm{A}}$ & $0.909 \pm 0.00^{\mathrm{A}}$ & $0.909 \pm 0.00^{\mathrm{A}}$ & $0.909 \pm 0.01^{\mathrm{A}}$ & $0.909 \pm 0.01^{\mathrm{A}}$ & $0.908 \pm 0.00^{\mathrm{A}}$ \\
\hline & Day 10 & $0.975 \pm 0.00^{\mathrm{A}}$ & $0.953 \pm 0.00^{\mathrm{B}}$ & $0.953 \pm 0.00^{\mathrm{B}}$ & $0.951 \pm 0.00^{\mathrm{B}}$ & $0.952 \pm 0.00^{B}$ & $0.955 \pm 0.00^{\mathrm{B}}$ \\
\hline \multirow{2}{*}{$\mathbf{L}^{*}$} & Day 1 & $83.14 \pm 1.22^{C}$ & $84.64 \pm 0.23^{\mathrm{B}}$ & $84.92 \pm 0.10^{\mathrm{B}}$ & $85.51 \pm 0.49^{\mathrm{AB}}$ & $86.78 \pm 0.17^{\mathrm{A}}$ & $86.77 \pm 0.30^{\mathrm{A}}$ \\
\hline & Day 10 & $80.99 \pm 0.77^{\mathrm{E}}$ & $83.28 \pm 3.11^{\mathrm{D}}$ & $84.81 \pm 0.13^{C}$ & $85.32 \pm 0.38^{\mathrm{BC}}$ & $86.55 \pm 0.20^{\mathrm{A}}$ & $85.92 \pm 0.30^{\mathrm{AB}}$ \\
\hline \multirow{2}{*}{$\mathbf{a}^{*}$} & Day 1 & $0.37 \pm 0.04^{\mathrm{D}}$ & $0.19 \pm 0.01^{\mathrm{E}}$ & $0.96 \pm 0.02^{\mathrm{A}}$ & $0.69 \pm 0.01^{\mathrm{B}}$ & $0.53 \pm 0.01^{\mathrm{C}}$ & $0.49 \pm 0.02^{\mathrm{C}}$ \\
\hline & Day 10 & $1.26 \pm 0.02^{\mathrm{A}}$ & $0.84 \pm 0.01^{\mathrm{C}}$ & $1.03 \pm 0.01^{\mathrm{B}}$ & $0.78 \pm 0.01^{\mathrm{D}}$ & $0.67 \pm 0.01^{\mathrm{E}}$ & $1.03 \pm 0.02^{\mathrm{B}}$ \\
\hline \multirow{2}{*}{$\mathbf{b}^{*}$} & Day 1 & $15.68 \pm 0.32^{\mathrm{B}}$ & $16.26 \pm 0.34^{\mathrm{B}}$ & $16.97 \pm 0.38^{\mathrm{A}}$ & $16.97 \pm 0.33^{\mathrm{A}}$ & $17.33 \pm 0.83^{\mathrm{A}}$ & $16.52 \pm 0.54^{\mathrm{AB}}$ \\
\hline & Day 10 & $19.13 \pm 0.73^{\mathrm{A}}$ & $18.41 \pm 0.20^{\mathrm{AB}}$ & $18.25 \pm 0.01^{\mathrm{ABC}}$ & $17.79 \pm 0.30^{\mathrm{CD}}$ & $17.46 \pm 0.08^{\mathrm{CD}}$ & $17.21 \pm 0.37^{\mathrm{D}}$ \\
\hline
\end{tabular}

$\mathrm{L}^{*}$ : lightness, $\mathrm{a}^{*}$ : redness, $\mathrm{b}^{*}$ : yellowness

Table 4B: Evolution of mesophilic and lactic bacteria during storage at $4{ }^{\circ} \mathrm{C}$ expressed in $\log$

\begin{tabular}{|c|c|c|c|c|c|c|c|}
\hline & & Control & $\mathbf{S A}$ & $\begin{array}{c}\mathrm{SA}+1 \% \\
\text { PSEO }\end{array}$ & $\begin{array}{c}\mathrm{SA}+2 \% \\
\text { PSEO }\end{array}$ & $\begin{array}{c}\mathrm{SA}+3 \% \\
\text { PSEO }\end{array}$ & $\mathrm{SA}+$ Vit C \\
\hline \multirow{4}{*}{$\begin{array}{l}\text { Mesophilic } \\
\text { bacteria }\end{array}$} & Day 1 & $3.89 \pm 0.02^{\mathrm{d}, \mathrm{A}}$ & $3.89 \pm 0.02^{\mathrm{d}, \mathrm{A}}$ & $3.89 \pm 0.02^{\mathrm{c}, \mathrm{A}}$ & $3.89 \pm 0.02^{\mathrm{d}, \mathrm{A}}$ & $3.89 \pm 0.02^{\mathrm{a}, \mathrm{A}}$ & $3.89 \pm 0.02^{\mathrm{c}, \mathrm{A}}$ \\
\hline & Day 4 & $4.30 \pm 0.01^{\mathrm{c}, \mathrm{A}}$ & $4.25 \pm 0.01^{\mathrm{c}, \mathrm{B}}$ & $4.26 \pm 0.02^{b, B}$ & $4.06 \pm 0.02^{\mathrm{c}, \mathrm{C}}$ & $3.97 \pm 0.02^{\mathrm{b}, \mathrm{D}}$ & $4.26 \pm 0.01^{\mathrm{b}, \mathrm{B}}$ \\
\hline & Day 7 & $5.44 \pm 0.01^{\mathrm{b}, \mathrm{A}}$ & $4.37 \pm 0.01^{\mathrm{b}, \mathrm{B}}$ & $4.29 \pm 0.02^{\mathrm{ab}, \mathrm{C}}$ & $4.14 \pm 0.01^{b, D}$ & $4.03 \pm 0.01^{\mathrm{b}, \mathrm{E}}$ & $4.39 \pm 0.01^{\mathrm{a}, \mathrm{B}}$ \\
\hline & Day 10 & $5.66 \pm 0.03^{\mathrm{a}, \mathrm{A}}$ & $4.42 \pm 0.01^{\mathrm{a}, \mathrm{B}}$ & $4.33 \pm 0.01^{\mathrm{a}, \mathrm{C}}$ & $4.20 \pm 0.01^{\mathrm{a}, \mathrm{D}}$ & $4.05 \pm 0.02^{\mathrm{b}, \mathrm{E}}$ & $4.41 \pm 0.01^{\mathrm{a}, \mathrm{B}}$ \\
\hline \multirow{4}{*}{$\begin{array}{c}\text { Lactic } \\
\text { bacteria }\end{array}$} & Day 1 & $3.27 \pm 0.01^{\mathrm{c}, \mathrm{A}}$ & $3.27 \pm 0.01^{\mathrm{c}, \mathrm{A}}$ & $3.27 \pm 0.01^{\mathrm{c}, \mathrm{A}}$ & $3.27 \pm 0.01^{\mathrm{c}, \mathrm{A}}$ & $3.27 \pm 0.01^{\mathrm{b}, \mathrm{A}}$ & $3.27 \pm 0.01^{\mathrm{d}, \mathrm{A}}$ \\
\hline & Day 4 & $3.58 \pm 0.01^{\mathrm{b}, \mathrm{A}}$ & $3.54 \pm 0.01^{\mathrm{b}, \mathrm{B}}$ & $3.40 \pm 0.01^{b, C}$ & $3.36 \pm 0.02^{b, C}$ & $3.33 \pm 0.01^{\mathrm{a}, \mathrm{D}}$ & $3.50 \pm 0.02^{\mathrm{c}, \mathrm{B}}$ \\
\hline & Day 7 & $4.07 \pm 0.03^{\mathrm{a}, \mathrm{A}}$ & $3.89 \pm 0.03^{\mathrm{a}, \mathrm{B}}$ & $3.74 \pm 0.05^{\mathrm{a}, \mathrm{C}}$ & $3.52 \pm 0.03^{\mathrm{a}, \mathrm{D}}$ & $3.33 \pm 0.08^{\mathrm{a}, \mathrm{E}}$ & $3.91 \pm 0.01^{b, B}$ \\
\hline & Day 10 & $4.08 \pm 0.03^{\mathrm{a}, \mathrm{A}}$ & $3.92 \pm 0.07^{\mathrm{a}, \mathrm{B}}$ & $3.78 \pm 0.02^{\mathrm{a}, \mathrm{C}}$ & $3.53 \pm 0.05^{\mathrm{a}, \mathrm{D}}$ & $3.35 \pm 0.05^{\mathrm{a}, \mathrm{D}}$ & $3.96 \pm 0.01^{\mathrm{a}, \mathrm{B}}$ \\
\hline
\end{tabular}

$\mathrm{CFU} / \mathrm{g}$ cheese

Control: uncoated cheese; SA: Cheese coated with sodium alginate solution only, SA + 1\% PSEO: Cheese coated with sodium alginate solution containing 1\% PSEO; SA + 2\% PSEO: Cheese coated with sodium alginate solution containing 2\% PSEO; SA + 3\% PSEO: Cheese coated with sodium alginate solution containing 3\% PSEO; SA + Vit C: Cheese coated with sodium alginate solution containing $1 \%$ of vitamin $\mathrm{C}$.

(a-d) Different subscripts indicate significant differences for the same sample within different days of storage $(p<0.05)$. (A-E) Different letters indicate significant differences between samples in the same storage day $(p<0.05)$. 
The authors certify that they have NO affiliations with or involvement in any organization or entity with any fi nancial interest (such as honoraria; educational grants; participation in speakers' bureaus; membership, employment, consultancies, stock ownership, or other equity interest; and expert testimony or patent-licensing arrangements), or non-fi nancial interest (such as personal or professional relationships, affiliations, knowledge or beliefs) in the subject matter or materials discussed in this manuscript. 


\section{Highlights}

- The main compound of Pimpinella saxifraga essential oil (PSEO) was anethole

- PSEO showed potential antioxidant and antibacterial activities

- The study of acute toxicity of PSEO showed that estimated LD D $_{50}$ was $939 \mathrm{mg} / \mathrm{kg}$

- Addition of PSEO in sodium alginate coating improved cheese preservation

- Sensory analysis showed consumer appreciation of coated cheese using PSEO 